\title{
Self-Awareness and Perception in Augustinian Epistemology
}

José Filipe Silva, University of Helsinki, jose.pereiradasilva@helsinki.fi

\begin{abstract}
Traditionally, two claims have been made about Augustinian views on selfknowledge: firstly, that according to Augustine the soul is fully transparent to itself, meaning that it has an unmediated access to its essence; secondly, that medieval Augustinians retained this unmediated access to the essence of the soul by itself, thus opting for a view alternative to authors of Aristotelian hue for whom the soul knows itself only by means of knowing its acts. In the first part of my paper, I argue that the traditional reading of Augustine is correct with the qualification that such transparency is proper to the human mind, which means that it does not apply to the soul of non-rational animals. Sensory self-awareness in non-rational beings must be understood in the restricted sense of awareness of the state of their sense organs. In the second part of my paper, I investigate how the principle of the soul's transparency is understood by a sample of late medieval thinkers with the aim of showing that the traditional distinction between Augustinians and Aristotelians on self-knowledge became progressively blurred.
\end{abstract}

\section{Introduction}

One of the problems when addressing medieval theories of perception is the conflation by medieval thinkers of two issues: one, the description of the processes by means of which information about particular objects in the external world is acquired, and two, the explanation of how we come to be aware of external things and their properties. Whereas the former is a question about the faculties and mechanisms of the perceptual process, the latter is about the phenomenology of perceptual experience. And it is in the latter that the issue of self-awareness has a role to play.

Another issue arises from the focus of many of the existing studies on medieval theories of mind and cognition that hold a real distinction between the soul and its powers, as well as of studies that are committed to strict faculty psychology accounts according to which knowledge acquisition can be reduced to a complex organogram of powers that perform specific tasks. By making the soul's cognition of itself (or whatever object) a function of a specific cognitive power of the soul rather than a function of the soul as such, this approach makes the question of understanding 
the role played by self-awareness particularly difficult to examine especially in what concerns the Augustinian model. In face of the task at hand, the suggestions here presented should thus be taken as clues for future research than a comprehensive account.

In this chapter, I focus on the connection between perception and selfawareness. In the first section of the paper, Augustine's theory of self-awareness is analyzed. To take Augustine (354-430) as the starting point finds its justification in his transparency account of mental life that seems, however, to be restricted to reason and exclude sensory awareness. I want to discuss this because it is an account that becomes very influential in the late middle ages. In the second section, I discuss some medieval thinkers on this topic, namely Matthew of Aquasparta (1240-1302), Henry of Ghent (ca. 1217-1293), James of Viterbo (ca. 1255-1308), Thomas of Sutton (d. 1315), John Pecham (ca. 1230-1292), and Vital du Four (1260-1327).

\section{Augustine}

It is a well-known notion that Augustine asserts the principle of the transparency of the soul, according to which human beings have direct access and knowledge of themselves. Augustine clearly asserts this when he says about the mind that

"Nothing can be more present to itself than itself."

The result of a theological demand, as the human mind mimics the divine Trinity, self-knowledge and love are intertwined: only what is known can be loved, ${ }^{2}$ which means that the mind loves itself because it knows itself. What is particularly important in this is that love of the kind Augustine envisages for the mind is absolute or all-encompassing and that is the result of absolute knowledge: there is nothing about itself that the mind fails to know. Let's call this the absolute-principle, which can be briefly formulated as follows:

\footnotetext{
${ }^{1}$ De trin. 10.3.5, 297. (Except otherwise noted, I refer to McKenna's translation.) Another formulation of the principle is found in De trin. 10.9.14, 308: "every mind knows and is certain concerning itself".

2 "For certainly something cannot be loved unless it is known." De trin. 10.1.2, 293.
} 
The absolute-principle is another way to express what some have called the principle of transparency in Augustine, that is, the thesis that the human mind is absolutely transparent to itself - which can be formulated in the following way:

According to this principle, the mind's awareness of itself is not dependent on a reflexive act through which it would take itself as the object of its own gaze. Instead, the mind simply knows itself as being and it knows itself to be what it is. ${ }^{3}$

There is however a major issue with this principle. Augustine has a way to both uphold this notion to the center of his thought and to be dismissive in taking it in a strong sense. The mind is in its post-fallen state weakened by a tendency to be distracted by, and impelled to, corporeal things in such a way that "it is incapable of being in itself without the images of those things" (De trin. 8.11, 305). As Augustine puts it in De musica VI, "the soul is a great thing, yet it does not remain capable of suppressing its own lascivious motions". ${ }^{4}$ This state of permanent distraction impedes the mind from fully concentrating on itself and being able to take itself as the object of its own gaze. ${ }^{5}$ This post-Fall circumstance does not affect the capacity but the exercise of that capacity.

In this sense, Augustine (and Augustinians) and Aristotle (and Aristotelians) stand in opposite ends of the spectrum in what concerns self-awareness: whereas for the latter it is the fact that the soul engages in cognition of external things that gives it the way by which it cognizes itself (i.e. the operations of knowing external things are, as it were, "facilitators of self-knowledge"), for Augustine (and Augustinians), the presence in the soul of images of external things is what prevents the soul from actually knowing itself immediately. Augustine develops this argument in a clarifying

\footnotetext{
${ }^{3}$ De trin. 10.10.16. PT fails to accommodate one important aspect in Augustine's theory, which B does not; the justification for absolute knowledge. As spelled out in $B$, the mind loves itself completely because it knows itself completely. There is something in B that is dear to the medieval approach to epistemology, which is never taken as an end in itself: knowledge is never self-justifiable but we know in order to fulfill our nature, adapt to the environment, or survive.

${ }^{4}$ De musica VI, 37.

${ }^{5}$ This is an interesting and clever distinction between what the mind is inherently capable of - absolute and immediate, direct knowledge of itself - and the mode of self-knowledge the mind exercises in the post-Fall human practice. The question arises however in what concerns self-awareness at the sensory level, that is to say, the kind, if any, of awareness the soul is capable of during the process by which it comes to know external things, objects and their properties.
} 
manner in what I call, in opposition of the famous Avicennian example of the flying or floating man, the "anchored man":

For what is so much in the mind as the mind? But because it is in those things of which it thinks with love, and it has grown accustomed to thinking of sensible things, that is, of bodies with love, it is incapable of being in itself without the images of those things. From this arises its shameful error, that it can no longer distinguish the images of sensible things from itself, so as to see itself alone. ${ }^{6}$

Augustine's remarks about the way in which the soul is disturbed by the continuous flux of sensory imagery that affects its concentration in a particular image, or in itself, can be found in many places. It is this presence, to which he refers in the last part of the passage just quoted, which makes it impossible for the soul to see itself without the images. But in the first part of the passage he goes further and complains that the soul cannot even be without images of sensible things (from which it cannot distinguish itself) thus making direct knowledge of the soul by itself problematic. ${ }^{7}$

Moreover, in this passage concerning the soul's ability to turn to itself, Augustine asserts the existence of images that fill the soul, which means that these images are somehow made present to the soul. The only way these images are in the soul is for the soul to either receive these images from external things - which he denies - or make these images from actually present objects - which he accepts. It has been argued that the process of image formation must in normal circumstances be unconscious. ${ }^{8}$ I agree with this assessment. This raises the question of what is the level of awareness involved in perceptual experience, ${ }^{9}$ in other words, whether the awareness of oneself as the subject of the perceptual experience is part of the perceptual experience itself. ${ }^{10}$ At a very general level Augustine seems to have to make a decision between two options. Either

(1) the soul is not aware of itself when perceiving (external things) because focusing on external things prevents thinking about itself

\footnotetext{
${ }^{6}$ De trin. 10.8.11, 305.

${ }^{7}$ Later on, an Augustinian such as Gerard of Abbeville will claim along the same lines, pointing out that only when liberated from considering external things can the soul turn upon itself and know itself. See Quodlibet IV, q.1, ed. A. Pattin, in L'Anthropologie de Gérard d'Abbeville. Leuven: Leuven University Press 1993, 26.

${ }^{8}$ See O’Daly (1987); Hölscher (1986), 68; and Sorabji (2006).

${ }^{9}$ Silva (2014).

${ }^{10}$ This is a very different question from the knowledge of the self. On this issue, see Remes (2008).
} 
or

(2) the soul is aware of itself even when perceiving external things.

There is at least one main problem for each option that needs to be addressed. Although (2) seems to be true on the basis of Augustine's commitment to PT, the fact is that he seems to explicitly deny it precisely because of his realist commitments: Augustine wants to be able to claim that when perceiving external things, only external things are the direct object of our perceptions - no representation takes their place, even if they figure as unperceived intermediaries in the process. ${ }^{11}$ Although it is tempting to read Augustine as asserting some basic, primary, non-propositional sort of self-awareness, which would make sense especially in the case of human beings due to Augustine's commitment to PT, the textual evidence simply does not seem to warrant it, as I will try to show below. It is only by reason, the power that is capable of taking itself as the object of its own act, that the soul is able to distinguish between itself and the form of the thing present to itself.

As for (1), the problem is that the inaccessibility of some acts of the human soul to itself makes sense only if one takes some of them as not belonging to the part of the human soul that has complete knowledge of itself, i.e. the mind. Let me spell out this argument. According to (A), all acts of the mind are known by the mind. If, however, some acts are not immediately accessible to the mind, then, either (A) (and PT) is false or there is some part of the soul that is not the mind to which the transparency principle does not apply. However, Augustine dismisses in DT 10.4.6 the claim that the soul knows only part of itself: the soul, he states, knows itself completely, as a whole (tota).

In several places, but especially in De trinitate 10, Augustine frames the question of the mind's presence to itself in terms of a distinction between to know itself (se nosse) and to think of itself (se cogitare). As a consequence of the Original Fall, Augustine claims, the mind knows itself completely but does not think about itself all the time. The difference between thinking about $\mathrm{x}$ and knowing $\mathrm{x}$, applied to the soul's self-awareness, means that it is one thing for the soul to think about itself -

\footnotetext{
${ }^{11}$ Brittain (2002).
} 
which requires devoted attention and taking itself as an determinate object - and to know itself, which he takes to be an absolute affair, in that the soul knows itself as a unified totality of which no aspect is inaccessible. Moreover, acts of thinking or understanding something else come and go as long as memory makes the image of what is to be thought available to the "eye of the mind"; but knowing itself requires no such imagery as the mode of knowledge of the soul by itself is best described as continuous unmediated cognitive presence. $^{12}$

As we have seen before, when analyzing how the mind turns to itself Augustine points to the difficulty the mind faces of not being able to think (of) itself without the images of external things it so dearly loves but, in a way, these images are part of the soul itself - they are, as he says, made in and from the mind's essence. In knowing, the soul makes itself to be like the thing that is known, in such a way that the soul is not able to distinguish itself from the image. There seems to be no way for the soul to achieve the knowledge of itself as being that which is considered independently of having those images while informed by the images of sensory things. ${ }^{13}$ Distracted as it is by the world, the soul returns to itself and to the thinking of itself replenished with images it has made in and of itself of external things. ${ }^{14}$ When the mind thinks of itself, then, it thinks of itself together with the images of external things.

One may wonder about the validity of this account, that is how can the mind know itself completely if it does not know what it does - e.g. paying attention to external things present to its senses - when it does not think about itself. The fundamental distinction between knowing its own essence and not knowing its own acts is fruitful only if one takes the acts as qualities, thus, accidents. But when considering the knowledge of itself via the knowledge of external things the distinction between knowing itself and thinking of itself seems to yield little explanatory power.

However, it does. When Augustine asserts that the soul is not capable of discriminating between the soul and the image of the thing but is able to distinguish the form of the thing in the thing and the form of the thing in the soul (De trin. 10.6.8; 11.2.3), what he is in fact saying is that the former distinction is sensory in nature,

\footnotetext{
${ }^{12}$ De trin. 10.3.5; 14.10.13; see also Hölscher (1986), 129.

${ }^{13}$ De trin. 10.8.11. This is the distinction between interiority and exteriority of mental presence to which Hölscher $(1986,129)$ alludes.

${ }^{14}$ De Genesi ad litteram 12.16.33.
} 
whereas the latter is rational. Only reason performs this distinction, as he makes clear in the following passage:

Finally, it [reason or mind] directed its attention to the way in which the soul, of which it was the head, was active in moderating, activating, perceiving and retaining these rhythms, and it separated all these rhythms of the soul from the corporeal ones and recognized that it would not have been able to observe or distinguish or, at the very least, to enumerate all these things without some rhythms of its own, and it set these above the others of inferior rank through some kind of judicial evaluation. ${ }^{15}$

He concludes by noting that rhythmicity and harmony are only recognized by reason in conformity with higher rules, but the point that interests us here is the claim that only reason is able to determinately discriminate between the inner representation and the external thing, which implies that we have no access to this distinction in the perceptual experience itself. If discrimination between the image of the external thing and the thing itself is beyond the reach of any sensory power, ${ }^{16}$ being made only at the rational level, it cannot be a constituent of the perceptual experience itself. It seems therefore that this distinction, and the awareness of oneself as the subject of perceptual experience it entails, has no place in the phenomenology of perception.

How to explain, then, the often quoted passage from the second book of Augustine's De libero arbitrio where Augustine quite explicitly states that animals are aware of themselves perceiving. I quote the passage in full:

The internal sense not only senses the things it receives from the five bodily senses, but also senses that they are sensed by it. Animals would not move themselves to either pursue or avoid something unless they sensed themselves sensing - not for the sake of knowledge, for this belongs to reason, but only for the sake of movement - and they surely do not sense this by any of the five bodily senses. ${ }^{17}$

As the text makes clear, the animal is aware of the state of its senses, which I take to mean that it is awareness of the senses that is mediated by the awareness of the state

\footnotetext{
${ }^{15}$ De musica VI.10.25, 61 (emphasis added).

16 "We do not by the same sense distinguish the form of the body which we see and the form which arises from it in the sense of the one who sees because the connection between them is so close that there is no room for distinguishing them. But by our reason we conclude that it would have been utterly impossible to perceive anything, unless some image of the body that was seen arose in our sense." (De trin., 64.)

${ }^{17}$ De libero arbitrio $2.3 .9,39$.
} 
of the sense organs. ${ }^{18}$ This awareness of state is relevant for a teleological account of perception: to perceive is an essential function of animals that allows them to negotiate their way in their environment - this includes protecting themselves from dangers and pursuing what is essential for their survival. Perception is essential for the being, therefore all factors that prevent its normal functioning have to be addressed in the most efficient way possible.

The clause "unless they sensed themselves sensing" should be understood as meaning that unless animals perceive the state (functioning or not) of the sense organs, no action - avoidance or pursuit - on external things could take place. This much is clear but I would like to argue that this passage says less than what often has been thought. Despite Augustine's assurance that such internal sense is something we have in common with non-rational animals, I take it that he is only committed to granting to non-rational animals the awareness of the state of the sense organ, not the awareness of itself as the subject of a perceptual act. To claim that one is aware of oneself as the subject of a perceptual act clearly entails reason because no sensory act can have the reflexive nature required by this higher level of awareness. In other words, for Augustine human awareness is always rational, whereas there is no nonrational animals' self-awareness that is not awareness of the state of its sense organs by which I mean awareness of the senses as functioning or non-functioning to the exclusion of the awareness of themselves as existing subjects of experience.

The motivation for my suggestion is the distinction made by Augustine in the continuation of the text between sensing for the sake of knowledge and sensing for the sake of movement. Whereas the former is exclusive to rational beings, the latter is common to all animals. The different nature between rational and non-rational selfawareness is made explicit when Augustine remarks on how only through reason we know what is the proper object of the different sense modalities and that the inner sense "reports to reason anything with which it comes into contact" (De libero arbitrio 2.3.9, 38). I think this is a problem in Augustine's account. It seems clear that somehow the awareness of sensing must be perceived as being one's own, otherwise the teleological nature of the process would be left unexplained; but Augustine does

\footnotetext{
${ }^{18}$ I therefore disagree with Juhana Toivanen when he claims that Augustine attributes "the awareness of oneself as a living being to animals" (Toivanen [2013a], 357). I think Augustine is committed to a weaker version of self-awareness, which is the awareness of the state of the sense organs, that is, only to the idea that "animals perceive the functions of their bodily parts" (idem, 366). We certainly agree on the teleological nature of self-awareness for Augustine.
} 
not make this move explicitly. I would like to argue that Augustine need not to spell out this claim because in the case of human beings the awareness of oneself as the subject of all acts is already implicit in PT. The distinction between sensing for the sake of movement and for the sake of knowledge comes into play here because it shows how this kind of self-awareness does not apply non-rational animals.

Sensing for the sake of movement can largely be explained with processes happening at the sub-personal level - i.e. processes taking place without the subject being aware that they are taking place - even if these processes lead to the animal's action. The awareness of the state of the sense organs should be understood as a safeguard verification mechanism that allows the system, through the power of the inner sense, to check that the senses are operating under the normal conditions necessary for perception of external things. No self-awareness in a strong sense is required for such an operation. But in the case of rational animals this needs to be followed by the awareness of itself as the subject of that particular perceptual experience and of the object as that which is perceived in that perceptual experience and - this is the crucial bit - as being (identifiably) such and such. It is by reason that we know that we have an inner sense and also by reason that "[w]e hold anything that we know as something" (De libero arbitrio 2.3.8, 37). No non-rational animal can have such an experience because the nature of its content is different.

The relevant point here is that for the subject to react to the environment, a low level of self-awareness is sufficient. However, for the perception of the external thing the subject has to (i) be aware of itself as the subject of the perceptual experience (in Augustine's troubled terminology, of itself as having the image of the external thing) and (ii) perceive the external thing. When Augustine says that reason is able to discriminate between the internal image and the external thing, he is doing precisely that. Although often the mind thinks of itself as not being distinct from those external things (De trin. 10.12.19), it can bring itself into full consciousness. So the contrast that seems to result from Augustine's account of self-awareness is that between a very low level of awareness that takes place in perceptual experience and includes only the awareness of the state of the sense organs, and the human capacity of second-order acts of self-awareness, by means of which one is able to discriminate between oneself and the image of anything external being perceived. The latter is a rational activity. Finally, the mind is also able to know itself completely and to think about itself. Awareness of oneself as the subject of perceptual acts is part of rational 
self-awareness but this requires a reflexive act of the subject, requirement nonrational animals cannot fulfill.

Augustine seems to leave in inheritance to his medieval disciples the view that in contrast to his transparency principle, self-awareness in perceptual experience plays no role in a strong sense in constituting the perception of external things, ${ }^{19}$ except in registering the awareness of the state of the sense organs through which perception is effected. What seems to be missing in his account is, on the one hand, the distinction, to be found explicitly only in Peter John Olivi (c. 1248-1298), ${ }^{20}$ between the (direct) experience of oneself and the knowledge of the essence of the soul, and on the other hand, the notion that the experience of an act as being one's own is included in the act itself, a view that seems to be found only in Walter Chatton (c. 1290-1343). ${ }^{21}$ I have something to add to this by considering the view of Vital du Four in the context of medieval Augustinian (and others) accounts of self-awareness, some of which have received limited philosophical attention.

\section{Medieval Augustinians (and others)}

The influence Augustine exerted on medieval authors is explained not so much by the comprehensiveness of his thought as by how he framed the questions related to human epistemology and anthropology. It is the approach and certain of its basic ontological commitments that appear influential to later debates rather than the exact formulation of the theory (it also explains why Augustine is so often used as an authority by both sides of any given debate). My aim in this section is to understand how late medieval Augustinians interpreted the Augustinian conception of the transparent soul. I argue that the trade-off for the late medieval Augustinians' subscription of the principle of transparency is the intellectualization of perception. What I mean with the latter is that the major trend is to transfer the discussion on selfawareness even if of a basic kind to the intellect, with prejudice to sensory selfawareness. Due to Aristotelian influences, ${ }^{22}$ which are manifested in the terminology they use and the solutions they adopt, late medieval Augustinians seem uncertain

\footnotetext{
${ }^{19}$ On this conclusion, see Hölscher (1986), 83.

${ }^{20}$ Putallaz (1991), 94. See also Toivanen (2013b) and Rode (2008).

${ }^{21}$ See Yrjönsuuri (2007), 147-148; and Brower-Toland (2012).

${ }^{22}$ On this, please see T. Scarpelli Cory, Aquinas on Human Self-Knowledge. Cambridge: Cambridge University Press, 2014, 17-29.
} 
about how to conceive the soul's access to itself, becoming clearly divided on whether the soul becomes aware of itself via a species formed in the process of exercising its cognitive powers or via knowledge derived from the awareness of its own acts. It is around this division that this section is organized.

\section{Via species}

My starting point is Matthew of Aquasparta. For him, the activity of the soul is a necessary condition for the soul to take itself as the object of knowledge; but this taking itself as the object of knowledge is not a function of the sensory part of the soul. Reminding the reader of Augustine's example (in De musica VI) of the blind man who cannot fake an imagination of color, Matthew argues that even if there were no perceptual experiences the soul would, nevertheless, know itself. ${ }^{23}$ Matthew's argument is clearly aimed at the view, which Matthew associates with Avicenna (980-1037), according to which apprehensive powers are only brought into operation by their objects. ${ }^{24}$ In other words, for the soul to know itself it must be operating on some object be it internally or externally terminated. Matthew starts by denying this view, claiming that the soul knows itself even when not excited by external things, ${ }^{25}$ that is to say, the soul does not require the mediation of a sense image or an act of the soul in order to know itself. In the end, however, Matthew tampers with his argument to a compatibilist view, concluding that the soul both knows its essence directly and formally (formaliter) via species and objectively (obiective) through its essence. It knows itself through its essence but this knowledge is undetermined and general, only specified by knowing itself through a species. ${ }^{26}$ The soul needs to know itself in a particular and determined way via a species in the same way as it knows anything else, that is an image needs to be presented because knowing in act is to see that image. ${ }^{27}$. Such a solution is built on Augustine's original proposed distinction between the soul's knowing itself and thinking about itself.

\footnotetext{
${ }^{23}$ Quaestiones disputate de cognitione 5, 12, 295.

${ }^{24}$ Quaestiones disputate de cognitione 5, 5, 293. Interestingly enough, Matthew also uses Avicenna (and his flying man argument) to argue for the opposite view, that the soul has direct knowledge of itself (Questiones disputate de cognitione 5, 12, 312).

${ }^{25}$ Quaestiones disputate de cognitione 5, 12, 295.

${ }^{26}$ Quaestiones disputate de cognitione 5, 14-15, 313.

${ }^{27}$ Quaestiones disputate de cognitione 5, 306. Matthew repeats this same point in his Quaestiones disputatae de anima beata, q. 8, 346. For a detailed examination of Matthew's doctrine of selfknowledge, see Putallaz (1991).
} 
John Pecham makes a similar point when he asserts that the soul is both the efficient cause of the knowledge of itself and that it requires the existence of a likeness of itself, which informs the intellect, in order to know itself. ${ }^{28}$ Pecham argues against the need to posit self-knowledge to be mediated by the soul's knowledge of something else, stating that it knows itself by means of its own act as knowing itself knowing. ${ }^{29}$ Like many in this tradition, Pecham connects self-knowledge to the immateriality of the soul, which makes it capable of reflective acts i.e. turning on itself. That is unproblematic in what concerns those cognitive faculties of the soul, such as the intellect, which operate without any bodily organ but problematic in what concerns those (sensory) powers that operate through bodily organs. Pecham admits, however, that there is a sense in which even the sensory part of the soul is capable of some sort of self-awareness that is not dependent on turning on itself:

Although none of the sensory powers, despite being apprehensive powers, reflects upon itself the sensitive soul senses itself sensing, as the common sense senses itself sensing through the proper senses. $^{30}$

What Pecham is arguing here, although he does not elaborate further on it, is for the existence of a very basic kind of self-awareness, restricted to the operation of the common sense that is shared by all beings sentient. Only the common sense escapes the restriction to the general principle that no sensory power exercises its own operation upon itself. Pecham claims that to imagine oneself imagining is impossible because it would require a level of immateriality that is beyond the reach of sensory powers. $^{31}$ At the higher intellectual level, Pecham goes on to claim that the soul generates a likeness of itself that informs the eye of the mind, as Augustine says in De trinitate 14.8 , by means of which it sees itself.

Another author who conflates the soul's knowledge of itself with the soul's activity in perception is James of Viterbo, a canon of the Augustinian Order. James

\footnotetext{
${ }^{28}$ Pecham talks of the eye of the intellect or mind, which is a typical Augustian expression to describe understanding or grasping of a certain content by the mind, a mental analogue of corporeal vision. On this, please see e.g. De trin. 11.7.11-9.16; 12.14.23. See also M. Miles, "Vision: The Eye of the Body and the Eye of the Mind in Saint Augustine's 'De trinitate' and 'Confessions", , The Journal of Religion 63:2 (1983), 125-42.

29 “... intelligit se per actum suum in quantum intelligit se intelligere” (Quodlibet IV, q. 27, 236).

30 "Cum tamen nulla virium sensitivarum super se ipsam reflectatur, quia tamen apprehensivae sunt, anima sensitiva sentit se sentire, sensu enim communi sentit se sentire sensu particulari." (Tractatus de anima, ch. $12, \uparrow 2,42$.)

31 "Nullus enim imaginatur se imaginari, nec aestimat se aestimare"( ibid.).
} 
has a fuzzy theory of perception, whose starting point is the conception of the soul as having undetermined potentialities for knowing certain kinds of things. These potentialities come into full realization when they are excited by the presence of the external thing (or its species), via the senses. Now, James takes it that in the case of the soul's knowledge of itself there is equally an innate aptitude for knowing itself but for this the activation cannot come from the outside.

The solution is to argue for two distinctions, one general between the soul (its substance) and its operation(s), and one special between the soul as the agent of knowledge and the soul as the object of knowledge. When the soul is engaged in the knowledge of external things, by being excited by the presence of the phantasms, the soul comes to be aware of itself (percipit se) as knowing the external thing (via the phantasm). ${ }^{32}$ This implies making from itself a species of the object to be known (in this case, of itself) that, as James remarks, is just the way the soul knows. ${ }^{33}$ Knowing that this constitutes a departure from Augustine's theory, James clarifies that what Augustine meant by species is just the aptitude to know (itself). ${ }^{34}$

This kind of self-awareness that is the knowledge of itself as being is described by James as being indistinct and imperfect, ${ }^{35}$ which is followed by a perfect and distinct knowledge of itself as being such and such (i.e. the knowledge of its essence). However, such perfect knowledge is out of reach in this life: the most the soul is given to know about itself in the present state is that it is a spiritual substance born to subsist on its own. ${ }^{36}$ This knowledge is achieved partially as the result of a process of comparison with the body, which the soul perfects and informs, but that is not available through direct perception. It becomes clear from his account that James assigns self-awareness to the intellect, rather than to any sensory power, precisely because to be aware of itself is a higher cognitive function that requires a fully spiritual substance.

\section{Via acts}

\footnotetext{
${ }^{32}$ James states clearly that these are two consecutive acts: the soul first perceives the external thing, then it becomes aware of itself as perceiving the external thing ("anima ... ducatur primo in cognitionem alterius a se; et per illius cognitionem venit in cognitionem sui ipsius", Disputatio prima de Quodlibet, q. 14, 196 [emphasis added]).

33 “... ab ipsa producitur” (Disputatio prima de Quodlibet, q. 14, 197).

${ }^{34}$ Disputatio prima de Quodlibet, q. 14, 197.

35 “... cognitio indistincta et imperfecta” (Disputatio prima de Quodlibet, q. 14, 196).

${ }^{36}$ Ibid.
} 
The other indirect way for the soul to come to know itself is through the knowledge of its own acts. In his Quodlibet I, questions 12-13, Henry of Ghent argues that if the soul is on its own actually intelligible, the intellect, which is the power of the soul that knows intelligible things in act, cannot but know itself. Henry qualifies this form of self-knowledge as not taking place via any species but rather via the act of knowing. The argument is worth presenting in full:

However, it does not cognize by means of a species brought forth from itself, it is argued, because it cannot bring forth a species except by generating it by means of its own act of understanding and in this way it would cognize before generating the species by means of which it would cognize; and the question could be raised about the act of cognizing: whether it cognizes by means of the species brought forth from itself; and this would either go on endlessly or to the point that it cognizes without a species brought forth from itself. ${ }^{37}$

Henry makes clear the point that the soul's self-knowledge is mediated by its own act of knowing. The exception is the disembodied state when, separated from the body, the soul is free to turn to itself and to know itself directly, in other words, to fully exercise the reflexive powers that follow from its simple and immaterial nature. ${ }^{38}$

Decades later, Vital du Four claims that although the primary objects of the intellect are universals, the intellect is able to have knowledge of singular objects. ${ }^{39}$ But this could be understood, he says, in one of two ways: either the intellect has indirect knowledge, that is to say, knowledge that results from information acquired through sensory experience, or the intellect has direct, immediate, access to the sensory information, which means that it has to access this information when this information is acquired - i.e. while the perceived object is still present to the senses. There is no question that the intellect acquires information in the former way: that is

\footnotetext{
37 "Quod autem non intelligat specie edita a se, arguebatur, quia non potest speciem edere a se nisi gignendo ipsam suo actu intelligendi et sic prius intelligeret quam speciem qua intelligere debet gigneret; et de illo actu intelligendi priori posset esse quaestio an ipso intelligit specie edita a se; et procedet in infinitum aut erit status quod intelligit sine specie edita a se." (Quodlibet I, qq. 12-13, 78.) Henry presents a similar argument about the species of the species in Quodlibet IV, q.7. In this Section, all translations are mine, unless otherwise noted.

${ }^{38}$ Henry remarks that Augustine's statement in De Trinitate that the soul has direct/unmediated access to itself is meant to apply to this disembodied state.

${ }^{39}$ On Vital du Four, see Lynch (1972). I take Vital's theory to be an example of what I would like to call "the intellectualization model" of late medieval Augustinianism in the philosophy of perception. I cannot go into the details of this strand of Augustinianism here but will simply state that it brings back something that sits at the heart of Augustine's Neo-Platonism, namely the conception of the soul as a unified entity that is in the case of human beings rational all the way down. Further studies will allow us to evaluate the central commitments of this model and how common it was in the late medieval period.
} 
described in the traditional model of abstraction, according to which the lower is ordained/directed (ordinatur) to the higher. But, Vital advances, it must also have unmediated access because only in this way it can know something as present and as existing (actualis existentia rei corporalis sensibilis). Vital argues that this "experiential cognition" (experimentativa cognitio) is justified by the principle that all cognitive powers are connected, a claim he explains in the following passage:

I say that, when it is said that the intellect influences all cognitive powers in their actuality in the way of a universal created cause, is present and cooperates with the particular causes, it must not be understood [as meaning] that [those] particular causes would operate without the influx from something superior, as long as their actuality would be preserved and the close patient [would remain]. [...] But I say that all apprehensions of the sensory [powers], whether of the particular senses or of phantasy, are perfect [insofar as the] genus of cognition [is concerned] but would be monstrous were it not for the intellect perfecting them. ${ }^{40}$

As the passage clearly shows, the higher cognitive powers influence the lower powers but Vital does not specify how the intellect perfects those lower powers. He has already suggested previously in the text that this influx is the result of the intellect's being the terminus of the powers' activities and that as such it affects the nature of the powers where it influxes - the terminus of a line defines the nature of the line. In other words, because in human beings low-level sensory processes are the first stages of higher-level cognitive processes, this already changes the nature of the lower processes. In the same way that, as Vital points out, the existence of the common sense in animals changes the nature of the activities of the senses, the existence of the intellect further up in the soul's cognitive pathways makes the sensory activities different - rational, in a way. Although Vital does not himself connect this with Augustine's passage from De libero Arbitrio, it seems to clearly follow from it. According to the passage, although (non-rational) animals share with human beings similar sensitive functions, these are essentially different in the two because of the purpose these functions serve, which in turn is dependent on what kind of beings they exist in. In the case of (non-rational) animals, perception has the purpose of survival,

\footnotetext{
40 "Dico quod, cum dicitur quod intellectus omnibus potentiis cognoscitivis in sua actualitate tamquam causa universalis creata influit, praesens est et cooperatur causis particularibus, non est intelligendum quin causae particulares sine influx superioris aliquid operarentur, dummodo in sua actualitate conservarentur et patiens approximatum esset. (...) Sed dico quod omnes apprehensiones sensitivae, seu sensuum particularium seu phantasiae, omnes sunt perfectae in genere cognitionis, sed monstruosae, nisi per intellectum perficiantur." (Huit questions, q. 1, II.1, 167; see Lynch [1972], 42.).
} 
pursuing beneficial things in the environment and avoiding harmful ones; but in the case of human beings, perception leads to knowledge and therefore its nature must be different from that of other animals.

The point is, then, that the kind of being something is changes the nature of whatever is received in it, a point Vital connects to the common Aristotelian dictum: whatever is received is received in the manner of the receiver (omne quod recipitur in alio recipitur per modum recipientis). This is true also in the cognitive sense - in fact, it is essential for understanding cognition. It applies to the intentionality of the species (in Aquinas as in others) but also, or especially, in what concerns the nature of the content of sensation: as the intellective (part of the) soul is the form of the human being, understanding, as the act of the intellective part, is communicated to the whole composite. $^{41}$

So, to be clear: what Vital is saying here is that I know $\mathrm{x}$ (an external thing) as being so and so and existing by means of an act that is both sensitive and intellective. It is sensory because it is performed by sensory powers via sense organs but it is rational because in beings endowed with reason, all acts are rational. If the soul is wholly in each part of the body, then, it is not only a particular sense power that informs a sense organ but the whole soul, including of course the intellect. ${ }^{42}$ In that sense it is the whole soul that perceives, not only the power of sight via the eyes. In the eye, the intellect apprehends for instance this white and that thing which is white, and in so doing, the intellect cognizes an actually existing external particular thing. This cognition, Vital claims, takes place not through the sense organs but in the sense organs. ${ }^{43}$

Vital is not, however, satisfied with the claim that the intellect is present in the senses in the way of influence, power and substance: he wants to go one step further and argue that the intellect is present in the senses on account of perfecting them cognitively. ${ }^{44}$

\footnotetext{
41 "Item, intellectiva anima in quantum intellectiva est forma hominis, ut patuit in quaestione de hoc disputata; omnis autem forma comunicat actum suum materiae vel saltem composito, ut ibi fuit ostensum; ergo necessario intelligere, quod est actus intellectivae, toti coniuncto communicabitur." (Huit questions, q. 1, 1, 157.)

42 "Item, ostensum est in quaestione De potentiis animae quod potentia intellectiva situm non habet in corpore, quia nullo organo utitur, sed est in omni parte corporis ut ibi ostensum fuit, quia illud in quo est, scilicet substantia animae, est in toto corpore" (Huit questions, q. 1, II.1, 166).

43 "not fit per organa sensuum, sed est in organis" (Huit questions, q. 1, II, 164).

44 "in ratione perficientis in ratione cognitive" (Huit questions, q. 1, II.1, 165).
} 
In the same way as the sun perfects the activities of inferior powers, the intellect perfects by its presence the activities of all cognitive powers, being the universal cause in cognizing in the microcosm in the same way as the Sun is [the universal cause] in generating. ${ }^{45}$

I take this to mean that sensory content is made cognitive by the presence of the intellect at a low level of processing sensory information. The suggestion is, therefore, that the content of human perceptual experience is cognitive because we are cognitive beings, that is to say, the intellect contracts its conceptual contents to the particular objects it cognizes while operating in conjunction with the (operation of the) senses. In this way, perception comes to have a conceptual nature because senses and the intellect operate jointly and intellectual cognition is about concepts. It is precisely this point that Vital makes shortly after, when he points out that

in the same way as the power of the sun, when it is conjoined with particular agents, is contracted and determined for instance with the power of this or that tree, and applied to the action of a particular [thing] becomes numerically one with it, also the intellective power, which is universal in cognizing, when conjoined with and applied to the particular sensory powers as it does when it understands and knows the actual existence of an external sensible thing, it is particularized and determined and contracted. $^{46}$

The result of the conjoined activity of the sun and the tree is a fruit, which in the case of sense and intellect is analogous to the content of the cognitive act, that is to say, what is acquired through the cognitive process. From the point of view of the intellect, the benefit of this conjoined activity is the cognition of the external particular existing thing. From the senses' point of view, the object is perceived as an individual thing, to which certain properties are attributed. ${ }^{47}$ Vital states clearly that by means of this conjunction of the senses and the intellect the higher cognitive power comes to know the external white thing because it is by means of the particular perceptual experience that it contracts 'whiteness' to this thing. The object of the

\footnotetext{
45 "Sicut igitur sol perficit actiones virium inferiorum, sic intellectus perficit praesens actiones omnium virium cognitivarum, cum in toto minori mundo sit causa universalis in cognoscendo sicut sol in generando." (Huit questions, q. 1, II.1, 168.)

46 "Unde, sicut virtus solis, dum coniungitur agentibus particularibus, contrahitur et determinatur, pote virtute huius arboris vel illius, et applicatur actioni particularis et efficitur una actio numero cum ea, sic virtus intelectiva, quae est universalis in cognoscendo, dum coniungitur et applicatur virtutibus particularibus sensitivis, quod fit dum intelligit et cognoscit actualem existentiam rei sensibilis extrinsecae, particularizatur et determinatur et contrahitur" (Huit questions, q. 1, II.1, 168).

${ }^{47}$ It may be that one recognizes that such properties are thereby also recognized as attributable to a certain kind of things, but this is highly speculative.
} 
intellect continues to be the universal but the contraction is done because cognition is realized via a particular sense that is in direct contact to a particular thing. ${ }^{48}$

Let us now turn to how Vital applies this general principle to the question of self-knowledge. ${ }^{49}$ A first caveat necessary to explain Vital's position is that the conjunction in operation of senses and intellect is said only of those acts that are directed to something external, not in the case of internal objects, such as the perceptual acts themselves. Self-knowledge is therefore about how the intellect is able to know itself knowing, that is the result of an operation of the intellect on its own, not in conjunction with the senses. Although grounded in the intellective substance of the soul, the sensory powers are different from it due to their connection to the sense organs, ${ }^{50}$ which being lower in the scale of being cannot subject the higher powers that inform them to the kind of influence that intellectual powers are able to exert.

Vital is equally adamant that the for the knowledge of the soul by itself no species is required; instead, he argues that the soul knows itself of knowing its effects, that is to say by knowing its operations, such as perceiving, living, and understanding. Vital describes this as an a posteriori and inferential (arguitive) mode of cognition, by means of which one infers from the operations it performs the kind of soul it is: from the operations related to sensation we know that the kind of being performing them is an animal and this knowledge can be further specified into the species of animal, still according to the knowledge of their operations. Vital points out that this mode has two important shortfalls: first, we know that the soul is but not what the soul is beyond a very general knowledge; second, such knowledge one has of its own soul is as limited as the knowledge one has of any other soul.

In order to secure the sort of knowledge one wants for the knowledge of oneself, something more is needed, which Vital discovers in the kind of awareness one enjoys experientially: I know myself - or, in his words, I know my soul to be and to be in me (animam meam esse et in me esse) - with a higher degree of certitude (certius) that I know your soul to be in you (in te esse). What explains this certitude is that I know it due to a certain experience of my acts as being mine (q.4, 233). Vital's original contribution is to take the certitude of the knowledge of my own soul to be

\footnotetext{
${ }^{48}$ Huit questions, 169.

${ }^{49}$ In what follows I do not bring anything new with respect to Lynch's detailed presentation of Vital's arguments but a systematic emphasis on what seems to be the original aspect of Vital's theory of selfknowledge: his insistence on the first person perspective and the certitude this brings to cognition.

${ }^{50}$ Huit questions, 163.
} 
dependent on its having a first person perspective: in other words, his claim is that I know that these are my acts because I have an experiential access to them that is not present when I experience acts being performed by someone else.

Vital takes this to be so important that he claims that certitude about one's knowledge of his/her own soul works as the principle of certitude about knowing anything else: whatever one knows, one knows with reference to oneself (quantum est ex parte mea, q.4, 234). In other words, whatever the mental activity I am engaged with is, I experience it as mine: it is my seeing, my willing. I experience myself willing (experior me velle, q.4, 242; q.4, 247). Vital refers to this experience of these acts as mine as 'internal experimentation' (experimentatione intrinsica) and 'experimentation of the mind' (mentis experimentatione, q.4, 247). What Vital is then doing here is to state as a primitive principle of cognition that 'it is impossible that someone knows by his act if it doesn't know that this is his act', which is followed by the inference that 'it is impossible that it knows that this act is his if it doesn't know that of which it is the act' (q.4, 235). The soul has no need for inbound species to know itself but it experiences its acts as their own (per actus suos intimos, quos experitur in se: q.4, 242).

I think this discussion is important in two ways: first, it is clear that the aim is not to argue for a phenomenological feel associated with the cognition of oneself but for the sort of certitude this first person perspective brings; second, he takes this sort of unmediated access (no species is required) to be a (justified) addition to Augustine's distinction between the soul's knowing and thinking about itself. And in a way this conception of self-knowledge works precisely because the object is not known as a determinate object. Let me explain this point: according to Vital, what one knows via the inferential mode of cognition is that the soul is (from its operations) and is in me (from internal experimentation), plus that it must be of a certain kind inferred from the kind of operations it performs. But that is still not to say that we know, as a result, what the soul is. For that we need to bring a different mode of cognition, one that is able to specify the object to be known into its proper or essential properties. In a way Vital is following Augustine closely in that he adopts the argument from the DLA (although he does not refer to this work in this place) that from the knowledge of what the soul does one comes to the knowledge of what are its properties. Another way of understanding this is to reflect on how the premise of me knowing these acts/operations as mine is implicit in Augustine, whereas it is the 
explicit core of Vital's proposal. For him, the knowing-thinking distinction is adapted into his account of threefold modes of knowing: there is knowledge that the soul is, there is knowledge that it is mine as its acts are, and there is knowledge of what it is.

Vital, therefore, strongly denies against other theories that our access to ourselves is dependent simply on either the knowledge of acts or species; instead, this access is in a way unmediated because it only works if we come to know our acts and our habits as ours. That is, even if we were to say - as some do - that we know ourselves via knowing our acts this is as such insufficient as an account of selfknowledge because these acts could be thought of belonging to someone else. Instead, what does the explanatory work is the experience of these acts (or habits) as mine. In order to prove his point he appeals to Avicenna's thought experiment of the flying man (q.4, 242), concluding that the soul has direct knowledge of itself even without any species from perceptual experience. On the contrary, he claims, it is by direct experiencing itself that the soul knows that and what it is. ${ }^{51}$ Again, the essential point here is not that it knows itself via the acts it performs but it knows itself via the acts that it experiences as being her own. I know with a higher degree of certainty (certius) that my acts of willing and understanding are mine than I know what my intellect and will are (q.4, 245). Nothing beats the first person experiential knowledge, even though this knowledge is undetermined or confused (in ratione indeterminata), as when I know that I am and live (me scire esse et vivere, q.4, 246).

A very important point for the purpose of this article is how Vital describes the power by means of which this self-knowledge is effected: this is the internal sense, ${ }^{52}$ which is intellectual and spiritual (sensus interior intellectualis et spiritualis) because it belongs to the non-organic part of the soul, that is the intellect (q.4, 244). In his words,

the unified soul knows itself being and inhere in the body through its intrinsic or extrinsic acts, without species; it knows those acts without species, by means of only the mind's experimentation as when I will that internal sense of the mind knows with absolute certainty and I experience myself willing. The soul does not have in this life the same certainty with respect to any other thing as it has of its own intrinsic acts: knows certainly itself willing, when it wills. ${ }^{53}$

\footnotetext{
51 'per actus suos intimos, quos experitur in se (...) devenit in sui notitiam et quia est et quid est', q.4, 242.

${ }^{52} \mathrm{He}$ also refers to it as the 'interior spiritual experiential (experimentante) sense' (q.4, 247).

${ }^{53}$ 'In hoc igitur residet huius quaestionis inquisitio, quod anima unita cognoscit se esse et corpori inesse per actus suos intrinsecos vel extrinsicos, absque specie; illos autem actus cognoscit absque
} 
In the continuation of the text, Vital connects this with Augustine's statement of PT, interpreting that principle as being about the certitude of self-knowledge that follows from the soul's experience its own acts as its own.

The inferential kind of self-knowledge allowed us to (i) know the acts of our soul as one's own and (ii) infer from this the power from which the acts (or habits) originate but left us with a very sketchy knowledge of (iii) the substance in which the acts (and habits) inhere. What Vital says in this context helps to clarify his view of rational influence on perceptual experience. It is, for him, impossible to know a thing from its accidents if one does not know what the thing is beforehand, that is to say, one can only proceed from the knowledge of the acts of a substance to the knowledge of the substance if one already knows the substance. ${ }^{54}$ This is a point that Vital makes in general, meaning that it applies to all things that are known through their effects as Lynch remarks, "some knowledge of the cause [...] must precede" and "will be specified and the nature determined through proper accidents". ${ }^{55} \mathrm{I}$ think this clarifies the point Vital was making earlier about the nature of the presence of the intellect in perception: the general, probably innate, knowledge it possesses prior to a particular perceptual experience is contracted by the particularity of the object in the experience.

For this more robust account of what the soul is, Vital moves on to the intuitive mode of cognition. Like the inferential mode, this is also not dependent on impressed species - that is, those having an external origin - but rather on what Vital calls expressed species - that is, produced by the soul in virtue of reflecting upon itself and expressing itself (q.4, 247-48). Although this can be seen as a needless complication, Vital explains that this is necessary to explain cognition in Aristotelian terms, that is to say as a kind of change or motion (for the explicit reference to Aristotle's Physics, see q.4, 250). The point Vital makes is that anything moving had been previously at rest, which means that motion needs to be explained by the introduction of a disposition that was not there before. The same is true with respect to self-cognition with the qualification that the new disposition cannot be caused by something external but by the soul itself. Whenever the mind turns upon itself it

specie, sola mentis experimentatione, ut, dum volo, sensus ille interior mentis certissime cognoscit et experitur me velle. Nec anima in hac vita naturali cognitione potest habere tantam certitudinem de aliquo quantam habet de illis actibus suius intrinsecis: scit enim se velle certissime, dum vult', q.4, 247.

${ }^{54}$ Huit questions, 253.

${ }^{55}$ Lynch (1972), 128. 
expresses its own essence to itself, by means of which becomes present to itself and known by itself (q.4, 248-50). This way Vital also explains away the original Augustinian distinction between the soul's knowing itself but not thinking itself all the time: only when abstracted from the flux of sensory information does the soul concentrate/turn upon itself by means of which it makes present and expressive of its essence and knows itself (q.4, 252).

Vital's account is in clear contrast to that found in one of his contemporary, the Dominican Thomas of Sutton. ${ }^{56}$ Describing the process through which one comes to know external things in his second Quodlibet, Thomas of Sutton raises the interesting question of whether corporeal vision is the same as the species of the thing seen. ${ }^{57}$ From the point of view of the object, perception is a transitive action in that the external thing being perceived passes on information about itself to any perceptual agent. The same is not true of the perceptual agent, whose action is to perceive the external thing by having its cognitive faculties actualized by the information presented by the external thing. Now, as Sutton rightly notes, the action of the perceiver is directed to the external thing in that it is about the external thing. In this sense, it is an intentional action, not transitive like the object's action. It is also intentional in another sense: whereas the object's action lacks intentionality in that the object issues forth a representation of itself when it is acted upon by natural agents (light in the case of color), the action of the perceptual agent is purposefully directed at knowing an external thing.

One possible objection at this point is to claim that the same happens in the case of perception, that is to say, the perceptual act is caused by the object's action, via its representation, on the sense organs and sense powers. This seems to be a fair objection if one accepts the object's causal efficacy, i.e. that perceptual acts are caused by the external things being known. It is here that the difference between Aristotelian and Augustinian philosophies of perception comes to the fore; subscribing to the former, Sutton concludes that perceiving is not an action properly speaking but rather a passion or a being acted upon.

\footnotetext{
${ }^{56}$ For a comprehensive account of Sutton's arguments, see Putallaz (1991), 191-257.

57 "Utrum visio corporalis sit idem quod species rei visae" (Quodlibeta II, q. 13, 264-269).
} 
Moreover, although the informing of the medium by the species is not cognition, the informing of the sense is cognition, although the sense does not act upon something when sensing but is merely acted upon - in the same way as the medium does not act but is acted upon. ${ }^{58}$

Augustinians took the intentionality of the soul towards the body as what makes perception possible, meaning that perception is an act of the vivifying principle of the body (the soul) and as such it cannot be caused by the contingent appearance of an external thing. Sutton sees it differently, though. He claims that the turning to the external thing to be perceived is not a function of the sensitive soul, which is a pure potency, but a motion of the appetitive power that connects the sensory faculty with the object. The image in the soul gains in ontological power by being received rather than produced - in the sense power. This jump in the ontological hierarchy is due to the epistemological nature it acquires by being a representation of something, thus nobler than the sensible quality that is received in the sense organ.

It is an indication of Sutton's view that the knowledge the soul has of itself is habitual knowledge that is only actualized (i.e., the soul actually thinks itself) when the soul cognizes something else. It is interesting that he combines the two forms of knowledge into one: "whenever it cognizes something, it perceives itself as being a knower, and now it knows itself because it perceives itself as being". ${ }^{59}$ In this sense, the soul continues to know itself habitually ("as being") even when it does not think itself.

Following the Aristotelian model, Sutton's theory is very efficient in granting reliability to our perceptions of external things, but it makes self-awareness more difficult to explain from an exclusively sensory point of view. By making perception a passive affair and the sensory power a pure potency, it removes from this perceptual level any discussion concerning how perceptual agents are self-aware when perceiving external things. Such a discussion is then moved into the intellectual sphere to be understood in the strictures of faculty psychology. That is why, as Putallaz describes in detail, most of Sutton's considerations on self-knowledge

\footnotetext{
58 "Ideo informatio medii per speciem non est cognitio, sed informatio sensus est cognitio, quamvis non agat sensus aliquid in sentiendo, sed tantum patiatur, sicut et medium non agit, sed patitur. Et propter hoc illa informatio licet non sit operatio vitalis, prout est in medio, tamen est operatio vitalis, prout est in sensu, quamvis sensus non agat ad illam operationem. Et quia species in sensu non accipitur sub ratione imaginis, nisi per intentionem animi sensus dirigatur ad sensibile et coniungatur et detineatur in illo, ideo informatio sensus per speciem non est sensatio, non est operatio vitae sine intentione animi sic coniungente." (Quodlibeta II, q. 13, 267.)

${ }^{59}$ Quodlibeta II, q. 14, 178.
} 
concern the nature of the intellect, its relation as a power to the (essence of the) soul, and the kind of intelligibility it achieves in its operation. But by making selfknowledge dependent on a specific functionally independent power, the intellect, it excludes from the outset the soul's transparency to itself. ${ }^{60}$

There is something intuitively appealing in this traditional understanding of self-awareness as dependent on the act of knowing something else: whenever the soul cognizes something else it can easily turn towards itself and perceive itself as being and as being that which cognizes something else (see Quodlibet II, q. 14, 274-275). The basic idea is then that immaterial agents are able to perceive themselves as the subjects of perceptual acts while performing those acts. From the Augustinian perspective that is hereby criticized, one of the problems with this theory is that its thesis of the dependence of self-perception on the act of cognizing something is a result, not the explanation, of a basic partition of the subject of those acts (the soul). In other words, the explanatory order in this account seems to be upside down. First the soul is partitioned into functionally different parts with its own set of powers. Then, immediate self-knowledge is denied on the basis of the distinction between the soul and its functionally distinct parts: the distinction requires that part $\mathrm{x}$ have objects of type $y$ (following the assumption that each function must have an object limited in scope), and part $\mathrm{x}$ is able to know itself when a type y image of itself is presented to it, which means that another power that is not $\mathrm{x}$ must bring about that image. By limiting the knowledge of the soul to the knowledge of its functionally divided parts, defined according to their objects, this theory restricts the scope of both the power and the object of knowledge. The 'knowing-via-act' is the result of the election of the principle of 'knowing-via-power', which is given a limited capacity. There can be no immediacy in the soul's knowledge of itself because the distinction into powers requires a distinction between objects. ${ }^{61}$ Instead, authors of the Augustinian hue accept this power-object specification concerning all things except the soul's

\footnotetext{
${ }^{60}$ Puttalaz (p. 204) notes that the assumption about the distinction between the powers of the soul and its essence is in the background of Sutton's arguments against the Augustinan view.

61 "Ex hoc etiam patet causa, quare anima non convertit se ad intelligendum se per suam essentiam. Oportet enim quod virtus cognoscitiva quaecumque ad illam partem se convertat in omni sua cognitione, ex qua parte animae est suum obiectum sibi proportionatum." (Quodlibeta II, q. 14, 282.) Sutton makes this explicit when he says that the intellect knows when (and only if) it turns to a phantasm, not to the essence of the soul (Quodlibeta II, q. 14, 279), the object of the intellect being the essence of a material thing (quidditas rei materialis). (See also Putallaz (1991), 207.) A power needs one object upon which to turn itself, and one is led to conclude that the object cannot be the whole soul. Sutton takes this impossibility - in contrast with the angels' knowledge of themselves - as axiomatic and grounded on the connection with the body.
} 
immediate access to itself because they take this kind of knowledge as primary. It is primary because it follows directly from the definition of the soul as an immaterial substance, with transparency deriving from simplicity. To fully flesh out this claim, however, would require a new study.

\section{Conclusion}

The present study argued in what concerns Augustine for a limitation in the scope of his account of self-awareness in perceptual experience, notwithstanding his subscription to the principle of the mind's transparency to itself. This is a limitation, not in the soul's capacity to access itself, but in the nature of what can be known when material things are known. At a basic level of information processing, Augustine seems to have no use for self-awareness, except for the awareness of the state of one's own sense organs. Only when reason intervenes in the process does the soul become aware of itself, which means that non-human animals are excluded from self-awareness in this stronger sense. Although it is possible to interpret him as saying that one is aware of the sense organs in a certain state as being one's own, and of oneself as being the agent of the perceptual experience, I take the existing textual evidence to be inconclusive on this.

Augustine seems to shy away from stating that the soul perceives itself as the subject of particular perceptual acts. The reason for this is that it seems to require a mediated awareness of the soul via the awareness of the soul's activities, e.g. when perceiving external things - as it will the case with Aristotelians. But this would go against the Augustinian idea that one can proceed from knowledge of the effects (or accidents) to knowledge of the cause (or substance) only if one already knows the cause, as Vital du Four would later point out.

In what concerns the medieval Augustinian discussion on self-awareness, this seems to be focused on intellectual awareness to the exclusion of a distinctly perceptual awareness. Despite the transparency principle remaining central to medieval Augustinians, this brief survey shows that when explaining the soul's mode of access to itself, they tend to accept that this access requires the mediation of cognitive acts, which either occasion self-knowledge by themselves or give rise to a species by means of which self-knowledge is effected. Both cases constitute a substantial departure from the original Augustinian position probably as the result of accommodating Aristotelian terminology and the way the discussion is framed. Such 
a development shows once more the depth of the interconnection and mutual influence between the two philosophical strands at play in the later Middle Ages.

\section{Bibliography}

\section{Primary sources}

Augustine (1894). Ed. J. Zycha. De Genesi ad litteram (Corpus scriptorum ecclesiasticorum Latinorum 28). Vienna, Prague \& Leipzig: F. Tempsky \& G. Freytag. English translation: J.H. Taylor (1982). The Literal Meaning of Genesis. New York: Newman Press.

Augustine (1968). Ed. W.J. Mountain \& F. Glorie. De trinitate. Turnhout: Brepols. English translation: S. McKenna (1963). The Trinity. Washington: The Catholic University of America Press.

Augustine (1970). Ed. W.M. Green. De libero arbitrio. Turnhout: Brepols. English translation: P. King. (2010). On the Free Choice of the Will. Cambridge: Cambridge University Press.

Augustine (2002). Ed. M. Jacobsson. De musica liber VI. Stockholm: Almqvist \& Wiksell.

Gerard of Abbeville (1993). Quodlibet IV. In A. Pattin (Ed.). L'Anthropologie de Gérard d'Abbeville. Leuven: Leuven University Press.

Henry of Ghent (1979). Quodlibet I. In R. Macken (Ed.). Henrici de Gandavo Opera

Omnia. Vol. V. Leuven \& Leiden: Leuven University Press \& Brill.

James of Viterbo (1968). Ed. E. Ypma. Disputatio Prima de Quodlibet. Würzburg: Augustinus-Verlag.

John Pecham (1989). Ed. F. Delorme. Quodlibeta Quatuor. Grottaferrata: Collegio S. Bonaventura Padri Editori di Quaracchi.

John Pecham (1948). Tractatus de anima. Ed. G. Melani. Florence: Biblioteca di Studi Franciscani.

Matthew of Aquasparta (1957). Quaestiones disputate de cognitione. Quaracchi: Typographia Collegii S. Bonaventurae.

Matthew of Aquasparta (1959). Quaestiones disputatae de anima beata. Quaracchi:

Typographia Collegii S. Bonaventurae.

Thomas of Sutton (1969). Ed. M. Schmaus \& M. González-Haba. Quodlibeta. München: Verlag der Bayerischen Akademie der Wissenschaften. 
Vital du Four (1927). Ed. F. Delorme. Le Cardinal Vital du Four. Huit questions inédites sur le problème de la connaissance. Archives d'histoire doctrinale et littéraire du moyen âge 2.

\section{Secondary sources}

Brittain, C. (2002). Non-Rational Perception in the Stoics and Augustine. Oxford Studies in Ancient Philosophy 22, 253-308.

Brower-Toland, S. (2012). Medieval Approaches to Consciousness: Ockham and Chatton. Philosophers' Imprint 12:17, 1-29.

Hölscher, L. (1986). The Reality of the Mind. London: Routledge \& Kegan Paul.

Lynch, J.E. (1972). The Theory of Knowledge of Vital du Four. New York: The Franciscan Institute.

Miles, M. (1983), Vision: The Eye of the Body and the Eye of the Mind in Saint Augustine's 'De trinitate' and 'Confessions'. The Journal of Religion 63:2, $125-42$.

O’Daly, G. (1987). Augustine's Philosophy of Mind. London: Duckworth.

Putallaz, F.-X. (1991). La connaissance de soi au XIIIe siècle. De Matthieu d'Aquasparta à Thierry de Freiberg. Paris: Vrin.

Remes, P. (2008). Inwardness and Infinity of Selfhood: From Plotinus to Augustine. In Remes \& Sihvola (2008), pp. 155-176.

Remes, P. \& Sihvola, J. (Eds.) (2008). Ancient Philosophy of the Self. Dordrecht: Springer.

Rode, C. (2008). The Concept of Inner Experience in Peter John Olivi. Bochumer Philosophisches Jahrbuch für Antike und Mittelalter 13, 123-141.

Scarpelli Cory, T. (2014), Aquinas on Human Self-Knowledge. Cambridge: Cambridge University Press.

Silva, J.F. (2014). Augustine on Active Perception. In J.F. Silva and M. Yrjönsuuri (Eds.). Active Perception in the History of Philosophy. From Plato to Modern Philosophy (pp. 79-98). Dordrecht: Springer.

Sorabji, R. (2006). Self. Ancient and Modern Insights about Individuality, Life, and Death. Oxford: Clarendon Press.

Toivanen, J. (2013a). Perceptual Self-Awareness in Seneca, Augustine, and Olivi. Journal of the History of Philosophy 51:3, 355-382. 
published in J. Kaukua and T. Ekenberg (eds.), Subjectivity and Selfhood in Medieval and Early Modern Philosophy. Springer, 2016, 157-79.

Toivanen, J. (2013b). Perception and the Internal Senses: Peter of John Olivi on the Cognitive Functions of the Sensitive Soul. Leiden: Brill.

Yrjönsuuri, M. (2007). The Structure of Self-Consciousness: A Fourteenth-Century Debate. In S. Heinämaa, V. Lähteenmäki \& P. Remes (Eds.). Consciousness. From Perception to Reflection in the History of Philosophy (pp. 141-152). Dordrecht: Springer. 